\title{
Canarias como escenario de cine: Nuevos caminos para el turismo y sus implicaciones económicas
}

\section{The Canary Islands as a privileged film set: New opportunities for tourism and economic development.}

\author{
AUTORES: \\ Jon Frías Mendi \\ (0000-0003-0838-7409) \\ Universidad Europea de Canarias \\ Enrique Carrasco Molina \\ (0000-0002-8683-5986) \\ Universidad Europea de Canarias
María Mercedes Sánchez de Armas
(0000-0003-2697-2847)
Universidad Europea de Canarias \\ Isabella Victoria Vidal Rodríguez \\ Universidad Europea de Canarias \\ Karl-Heinz Arvind Ermisch \\ Universidad Europea de Canarias
}

\section{Resumen}

El presente estudio aporta nuevos datos sobre las implicaciones económicas que derivan de la consolidación de diferentes zonas geográficas del Archipiélago como destinos para la producción cinematográfica. Con la puesta en marcha de ayudas especiales e incentivos fiscales, además de atractivas campañas que realzan las bondades paisajísticas de las Islas (Solá, 2016), Canarias ha intensificado su foco de interés turístico en la economía que se genera alrededor de grandes producciones cinematográficas/televisivas internacionales que, desde hace unos años, eligen este territorio para grabar. Aunque se trata de un tema abordado desde diversas ópticas, nuestro objetivo es que esta reflexión sirva para recoger los datos más actuales (hasta el presente año 2019) relacionados con el retorno económico y con la exploración de las nuevas potencialidades turísticas del sector.

\section{Abstract}

This study provides new data on the economic implications derived from the consolidation of different geographical areas of the Archipelago as destinations for film production. With the implementation of special aid and tax incentives, in addition to attractive campaigns that enhance the scenic benefits of the Islands (Solá, 2016), the Canary Islands have intensified its focus of tourist interest in the economy that is generated around large film productions / international television companies that, for a few years, have chosen this territory to record. Although it is a subject approached from different perspectives, our objective is that this reflection serves to collect the most current data (until this year) related to the economic return and the exploration of the new tourism potential of the sector. 


\section{Hipótesis}

H1: Canarias puede ser un destino competitivo que genere más riqueza y empleo atrayendo a más turistas por el mero factor de mostrarse como "escenario de cine".

\section{Metodología}

Se realiza una prospección académica que repasa la literatura científica sobre el particular y se realiza un análisis cualitativo y cuantitativo de datos económicos a partir de informes y fuentes contrastadas provenientes de administraciones competentes en materia de promoción turística.

\section{Introducción}

En las últimas décadas, la industria turística de Canarias se ha beneficiado de unas estrategias de segmentación impulsadas por distintas administraciones y organismos que han auspiciado el aumento de un turismo de más calidad (Hernández Martín, Santana Talavera, 2010), que gasta más, pero que al mismo tiempo exige más. El turista ya no es aquel ciudadano que venía a las Islas desde fríos países de origen, allá por aquellos años 60, 70 y 80, para broncearse sugestionado por el encanto de las playas y el seguro de sol. El viajero de hoy pide más calidad a los servicios que brinda la planta hotelera y extra-hotelera, espera que se cubran sus expectativas en cuanto atención personalizada, pero, sobre todo, busca complementar sus planes de descanso con incentivos adicionales que le proporcionen entretenimiento (parques temáticos de ocio), información cultural (museos), venta de productos tradicionales (mercadillos con productos de artesanía) y gastronomía de calidad (que, a ser posible, incluya alimentos y bebidas producidos localmente). En este marco se segmentación de destinos se ha venido comprobando el creciente interés que tienen cada vez más turistas en planificar unas vacaciones a Canarias informándose de antemano de los beneficios que aquí se pueden encontrar para el 'relax vacacional' pero, también, motivándose a disfrutar de calles, parajes, playas y montes donde sus actores de cine favoritos han protagonizado sus últimas películas o series. Pensemos en Silvester Stallone (Rambo V: Last Blood, 2019), José Coronado (Oro, 2016), Matt Damon (Jason Bourne, 2016), Brad Pitt/Marion Cotillard (Aliados, 2016), Chris Hemsworth (En el corazón del mar, 2015), Christian Bale (Exodus, 2014), Vin Diesel (Fast and Furious 6, 2013) o Sam Worthington (Ira de Titanes, 2012), por poner algunos ejemplos llamativos.

\section{Incentivos fiscales e impactos publicitarios}

Pero ¿qué atractivos encuentran las grandes productoras cinematográficas y televisivas para venir a grabar conociendo de antemano los grandes costes de transporte y logística?

Fundamentalmente por varios factores, entre otros, los incentivos fiscales de los que actualmente se pueden beneficiar las producciones cinematográficas, los alojamientos y servicios de calidad cercanos a los platós naturales, y los espacios para filmar que permiten un amplio abanico de inspiraciones escenográficas: desde los paisajes de ciencia ficción, o los acantilados mitológicos, hasta los bosques de ensueño, desiertos o playas paradisíacas (Pérez Guerra, 2018).

Sin embargo, entre las cuestiones que más interesan en este contexto se encuentran, por una parte, las ventajas de empleabilidad que se abren en el modesto tejido empresarial del audiovisual canario (compuesto por pequeñas productoras y compañías de apoyo logístico y equipamiento técnico), y por otra, los rendimientos económicos derivados de la propia actividad audiovisual. En este sentido, son reseñables los beneficios para comerciantes, minoristas y particulares que ceden sus tiendas, casas, terrenos 0 locales para emplazar cámaras y equipos, el empleo directo de personas contratadas para trabajar en figuración/extras y técnicos de productoras locales que apoyan los despliegues de filmación, y los abonos 
realizados por actores/actrices y equipos en hoteles, restaurantes y servicios adicionales (transportes, excursiones, visitas). Este último tipo de turismo podría adscribirse al segmento MICE (Meetings Incentives Conferences and Exhibitions).

A todo ello se le sumaría el valor que suponen los impactos publicitarios que logran enganchar a turistas que, además de conocer Canarias, desean 'pisar' en aquellos lugares donde han estado filmando o almorzando sus estrellas favoritas.

El Régimen Económico y Fiscal del que dispone Canarias como Región Ultraperiférica ha favorecido que el Archipiélago pueda ofrecer las mejores ventajas fiscales de todo el territorio europeo. Gracias a la Zona Especial Canaria (ZEC), las empresas audiovisuales radicadas en las Islas pueden beneficiarse de un tipo impositivo reducido del $4 \%$ en el Impuesto de Sociedades. Esto es debido a su singular régimen económico y fiscal, que incentiva las inversiones y la creación de empresas. En el caso de las producciones nacionales que se desarrollen en Canarias y que obtengan el Certificado Canario de Producción Audiovisual, los porcentajes de deducción son del $45 \%$ para el primer millón de euros, y del $40 \%$ en adelante, con un tope de 5,4 millones de euros (con lo que la base de deducción máxima se sitúa en los 13.375.000 €). Detrás de estas cifras es destacable el papel desempeñado por Canary Islands Film, una asociación sin ánimo de lucro constituida por una extensa red de Film Commissions y Film Offices en todo el territorio de España. Es miembro fundador de la European Film Commission Network (EUFCN) y trabaja en colaboración con instituciones audiovisuales, comerciales y turísticas de España.

El mundo del cine y las series de televisión se han convertido en una motivación para visitar los espacios en los que suceden todas las historias que nos cuentan a través de las pantallas. Queremos ser protagonistas, vivir lo que vivieron nuestros actores favoritos, ser estrellas por un momento y posar en los escenarios donde se rodaron las principales secuencias. La oferta de productos concretos relacionados con este sector aumenta a pasos agigantados. Existen rutas turísticas, páginas webs y redes sociales que nos muestran recorridos inspirados en las localizaciones de los films.

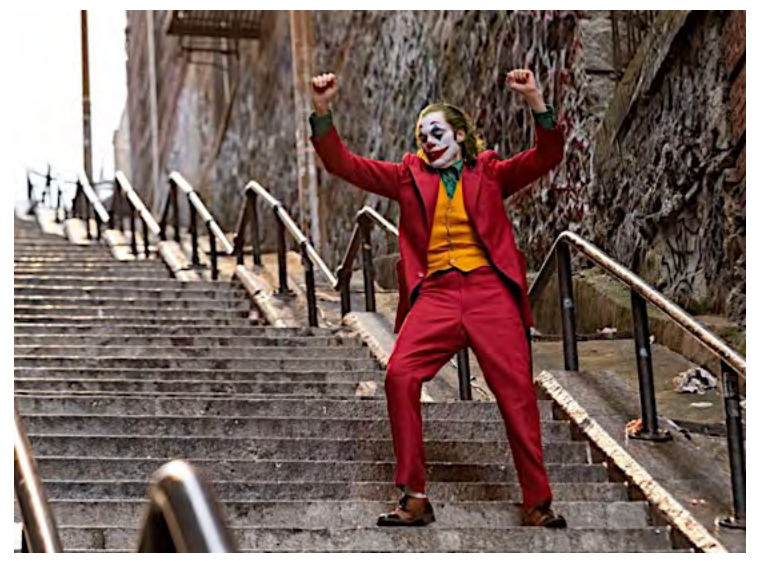

Foto 1: Una escena de Joker (Todd Phillips, 2019), en la que su protagonista, sumido en un particular declive existencial, desciende las escaleras del 1170 de Shakespeare Avenue, Nueva York (Gotham City en el film). Fuente: Warner Bros. Pictures. 
En Gran Bretaña, quien lo desee podrá seguir las huellas de Harry Potter o de los personajes de Outlander; El Hobbit puede ser un buen motivo para viajar a Nueva Zelanda; Juego de tronos ha llevado a numerosos turistas a Croacia, Marruecos, Islandia y, por supuesto, España. Y la recién estrenada Joker ha conseguido que las escaleras del 1170 de Shakespeare Avenue en el Bronx se hayan convertido en toda una atracción donde los forasteros posan como el villano más famoso de los comics para colgar después las instantáneas en sus redes sociales (Ovenden, 2019).

Siguiendo a la página web filtourismus.es o su Instagram podemos ubicar escenas concretas de películas y series en sus localizaciones gracias a que su autora saca fotografías en las que sustituye espacios reales con imágenes tomadas de las propias producciones. Así podemos ver donde ocurren secuencias específicas de Stranger things, La reina de África, Corrupción en Miami, Friends o Love Actually entre otras muchas más, convirtiéndose en un magnífico reclamo para los amantes del audiovisual.

Estas son simples muestras de lo que lleva ocurriendo ya unos años, así, según publica ElEconomista.es (2019), en la investigación Travelsat Competitive index de la consultora Tourism Competitive Intelligence (TCl) Research, queda reflejado que ya en el año 2012 el cine impulsó a unos 40 millones de turistas internacionales generando toda una industria alrededor del turismo cinematográfico.

\section{Canarias en el sector del turismo cinematográfico}

Matt Damon, Chris Hemsworth, Sylvester Stallone, Gal Gadot, Brad Pitt o Marion Cotillard - por nombrar tan solo a algunos de los profesionales que suelen pisar la alfombra roja en los Oscar y que tienen mayor repercusión internacional, pero sin olvidar a una gran cantidad de actores y actrices españoles y del resto del mundo- han conocido Canarias a través de su trabajo y gracias a la condición de 'film friendly' de la que disfrutan las islas. Precisamente este término de 'film friendly' ha sido acuñado recientemente en algunos contextos especializados en turismo y emprendimiento y se refiere a las privilegiadas condiciones del Archipiélago para acoger rodajes de todo tipo con una triple ventaja: el carácter polifacético y versátil de su paisaje, los incentivos fiscales y las condiciones estables de luz, sol y buen tiempo durante casi todo el año.

Y es que Canarias acoge cada vez más producciones con una enorme repercusión en las taquillas de todo el mundo. Sólo por nombrar a las más recientes, hace apenas unos meses que se estrenó la última entrega de Rambo, un poco antes fue Han Solo: una historia de Star Wars y en 2020 ha sido Wonder Woman 1984.

Todas estas creaciones y muchas más han venido al archipiélago atraídas por el enorme esfuerzo que lleva años realizándose para impulsar el progreso del sector audiovisual en las islas. Además del clima y las temperaturas que se pueden disfrutar durante todo el año y la posibilidad de encontrar cualquier tipo de localizaciones a poca distancia, el hecho de ofrecer el mejor marco fiscal de Europa (webtenerife.com, 2019) con grandes incentivos, las convierten en una opción que no deja indiferentes a los profesionales de esta industria.

Además, esta estrategia de desarrollo audiovisual está apostando por la formación de técnicos expertos en las diferentes áreas que engloba, de manera que las empresas que decidan rodar en Canarias encuentren todo lo que necesitan aquí tal y como se expone en un folleto promocional de Canary Islands Film: "Canarias cuenta con una industria audiovisual fuerte, preparada para producir y coproducir todo tipo de proyectos, y que ha sido reconocida con prestigiosos galardones cinematográficos". 
Los servicios que se ofrecen incluyen productoras, apoyo y gestión en la producción, alquiler de equipos, servicios especializados como por ejemplo seguridad, catering, asesores legales, actores y figuración internacional, platós de televisión, efectos visuales (VFX) y postproducción, bandas sonoras y compositores, festivales y mercados específicos, además de un Clúster Audiovisual.

Por todo esto, el número de trabajos que se han producido en Canarias ha ido aumentando año a año desde la creación de las diferentes Film Commission y con ellos el impacto económico que implican hablando de contratos a profesionales y empresas locales. Según se publica en la web de Canary Islands Film "2018 dejó cifras récord de producciones audiovisuales en Canarias", aportando también datos de impacto económico de cada isla, en Tenerife casi se alcanzan los 30 millones de euros y los trabajos realizados en Gran Canaria sumaron 15,8 millones de euros. Si hablamos de Fuerteventura, los últimos cuatro años han supuesto para la Isla más de 100 millones de euros (Canary Islands Film, 2019).

En cuanto al turismo cinematográfico, comienzan a ofertarse diferentes rutas relacionadas con las localizaciones de las grandes producciones que se han rodado aquí. Así el ayuntamiento de Las Palmas de Gran Canaria propone dos rutas de cine auto-guiadas que cuentan "icónicos rodajes de algunas películas que se han hecho hueco en el gran catálogo del Séptimo Arte, a nivel internacional, que se han convertido en títulos de gran seguimiento en taquilla o que también marcaron su propia huella en el cine español" (Ipavisit.com).

En Tenerife se puede seguir la ruta de Furia de titanes o la de Una hora más en Canarias, entre otras propuestas que están siendo desarrolladas y promocionadas por el organismo público Turismo de Tenerife. Esta organización ha tomado como ejemplos de inspiración algunas películas como Furia de Titanes o Una hora más en Canarias, cintas cuyos argumentos han cobrado vida en distintos parajes de Tenerife.

En virtud de esos rodajes, Turismo de Tenerife ha editado un material publicitario (web y folletos) en el que recomienda al turista acudir a esas mismas localizaciones o lugares cercanos, y, de paso, disfrutar de todos los valores turísticos inherentes a las zonas donde se han grabado algunas escenas de esas películas, como museos, restaurantes, oficinas de información, senderos, centros de visitantes, monumentos, recursos patrimoniales, parques temáticos, mercadillos, o centros de venta de artesanía, entre otras sugerencias.

Un caso que merece un análisis especial es el de la serie Hierro, rodada en 2018 en su mayoría en la isla de El Hierro a excepción de algunas escenas que se tomaron en Tenerife. Es una producción de Portocabo/ Atlantique Productions, Movistar y ARTE para Movistar+ y ha sido un auténtico escaparate de lo que se puede encontrar allí gracias a un cuidado trabajo de fotografía que recreaba toda la belleza de la isla del meridiano y que la convirtió en la principal protagonista de la serie.

Esta isla, una de las más pequeñas del archipiélago canario, es un escenario ideal para analizar la repercusión que ha tenido la serie en su turismo. Ya hay rutas para seriéfilos inspiradas en sus localizaciones, sólo habrá que esperar un poco para conocer el alcance de haber sido el personaje principal de la producción.

\section{Destino de inversión audiovisual}

Al tratar Canarias como destino de producciones tanto nacionales como internacionales debemos ubicar esta Comunidad Autónoma española dentro del mapa fiscal europeo e internacional. 
Canarias posee un régimen económico especial propio, Régimen Económico y Fiscal de Canarias (R.E.F.), que convierte a las islas en un polo de atracción, no ya solo del sector audiovisual, sino de muchos otros sectores. Solo analizando este régimen económico propio puede entenderse la atracción de inversión hacia el sector audiovisual que han experimentado las islas durante los últimos años. Estas medidas que favorecen un entorno de inversión en las islas las podemos agrupar en cinco elementos principales

(B.O.E., diciembre 2014):

- $\quad$ Reservas para Inversiones en Canarias (R.I.C.)

- Impuesto General Indirecto Canario (I.G.I.C.)

- Deducciones fiscales por inversión en producciones y coproducciones españolas

- Deducciones fiscales en producciones extranjeras

- Zona Especial Canaria (Z.E.C.)

Respecto a las R.I.C. el régimen especial canario permite la reserva por parte de las productoras audiovisuales de hasta un $90 \%$ de los beneficios generados para invertir en la propia empresa, quedando estos exentos de tributación por el Impuesto de Sociedades (I.S.). Esta figura implica una tributación, que será reducida, únicamente sobre el $10 \%$ de los beneficios, cumpliendo ciertos requisitos entre los que se encontrará la obtención del Certificado de Obra Canaria.

En lo relativo al I.G.I.C., este basculará entre tipos del 0-6,5\% (B.O.C., 2017), lejos de tipos impositivos como el Impuesto de Valor Añadido, con un tipo general del $21 \%$.

Las deducciones fiscales, tanto a productoras nacionales como extranjeras, has constituido un gran atractivo para estas empresas dentro de la industria audiovisual. Los porcentajes de deducción aproximan una idea de la importancia de estas deducciones: 40-45\% de deducción por inversión en producciones nacionales, $40 \%$ de deducción en producciones extranjeras. En el caso de las producciones nacionales, las inversiones deberán ir dirigidas a producciones de largometrajes y de series audiovisuales de ficción, animación o documental, aplicándose un $45 \%$ de deducción respecto al primer millón de euros de base de la deducción en crédito fiscal y $40 \%$ de deducción sobre el resto, con un límite de 5,4 millones de euros por producción. Para dar cuenta de la importancia de esta medida basta compararlas con las cifras de deducción aplicadas en el resto del territorio nacional, un 20\% con límite de 3 millones de euros por producción.

En el caso de producciones extranjeras nos encontramos un porcentaje de deducción del $40 \%$ en el caso de producción de largometrajes cinematográficos y de obras audiovisuales. Se aplicará esta deducción sobre los gastos realizados en la Comunidad, siempre que estos sean de al menos 1 millón de euros, o de al menos 200.000 euros si se trata de actividades de postproducción y animación, no pudiendo superar esta deducción los 5,4 millones de euros. Es importante resaltar que la productora deberá tener domicilio fiscal en Canarias, debiendo ser el presupuesto total de la obra de, al menos 2 millones de euros.

Finalmente, la Zona Especial Canaria (Z.E.C.) afectará positivamente no solo al sector audiovisual en las islas, sino a muchos otros sectores económicos, considerándose un motor de creación y crecimiento en la región. La Z.E.C. está constituida por una serie de medidas que buscan internacionalizar la economía canaria, la creación de empleo cualificado y la diversificación del tejido productivo. Fue autorizada por la Comisión Europea como una ayuda de Estado en enero de 2.000 y estará en vigor hasta 2.026, siendo 
esta fecha prorrogable. Esto le otorga plena seguridad jurídica, incrementada ésta a su vez al enmarcarse la región dentro de la Unión Europea y la O.C.D.E. Adicionalmente, la gestión de la Z.E.C se lleva a cabo a través de un Consorcio entre el Ministerio de Hacienda y el Gobierno de Canarias, lo que provoca un marco legal e institucional de cooperación entre los principales organismos nacionales y autonómicos.

La principal ventaja de la Z.E.C. se encuentra en el tipo reducido del Impuesto de Sociedades que se aplica en la Comunidad Autónoma de Canarias a determinados sectores. Según datos de Consorcio de la ZEC , esta tasa impositiva se sitúa en el $4 \%$, quedando lejos del tipo general del I.S. del resto de territorio nacional (25\%) (B.O.E, noviembre 2014), o de países como Irlanda (tipo súper reducido del 9\%).

Este tipo impositivo Z.E.C. se aplicará hasta un máximo de 1.800 .000 euros de base por creación mínima de empleo (3-5 trabajadores), incrementándose esta base en 500.000 euros por cada nuevo trabajador hasta 50 trabajadores (Consorcio ZEC, 2018). Una vez superados los 50 trabajadores todo el beneficio quedará sujeto, sin límites, al tipo del 4\%.. Respecto a la distribución de beneficios, ya vimos anteriormente las R.I.C. y el incentivo que suponen a que estos se queden en las empresas. Sin embargo, si se decide distribuir estos beneficios, estos quedarán gravados a tipos muy inferiores a los del resto de Europa, además de no sufrir una retención en origen ( $0 \%$ de retención, frente al $19 \%$ de retención del resto de territorio nacional).

Por otra parte, en relación a las actividades económicas que se pueden acoger a la Z.E.C encontramos entre otras, según datos del Consorcio Z.E.C. (2018), las TICs, I+D, energías renovables y actividades audiovisuales y de artes escénicas. Dentro de las actividades audiovisuales se considera como estratégica la producción, postproducción y distribución audiovisual, así como los servicios a productoras, según información de Canarias Z.E.C.

Una vez definida la situación fiscal especial canaria y su potencial de atracción de inversiones en el sector audiovisual, afrontamos el análisis de la inversión en el sector en Canarias.

Con datos de Canary Islands Film, facilitados por el Gobierno de Canarias sobre empresas audiovisuales que han solicitado acogerse a las ventajas fiscales que ofrece el territorio, observamos como el número de empresas audiovisuales que se han instalado en la Z.E.C desde 2015 en Canarias desde 2015 ha crecido de forma ininterrumpida hasta 2018. El Cuadro 1 muestra esta evolución, tanto en términos reales, como en variación anual y acumulada:

\begin{tabular}{|l|c|c|c|c|}
\cline { 2 - 5 } \multicolumn{1}{c|}{} & $\mathbf{2 0 1 5}$ & $\mathbf{2 0 1 6}$ & $\mathbf{2 0 1 7}$ & $\mathbf{2 0 1 8}$ \\
\hline Número de empresas & 6 & 8 & 14 & 18 \\
\hline Variación anual & & $33,3 \%$ & $75,0 \%$ & $28,6 \%$ \\
\hline Variación acumulada & & $33,3 \%$ & $133,3 \%$ & $200,0 \%$ \\
\hline
\end{tabular}

Cuadro 1: Evolución del número de empresas audiovisuales instaladas en la ZEC durante el periodo 201518. Fuente: Canary Islands Film y Gobierno de Canarias.

Puede observarse un crecimiento positivo constante, aunque más importante en 2017 con la atracción de 6 nuevas empresas audiovisuales. Estas cifras de crecimiento se continuaron en 2018 aunque a una tasa menor, con un incremento de 4 empresas instaladas en la Z.E.C, arrojando un crecimiento positivo del 
$28 \%$ anual. En términos acumulados, se observa cómo desde 2015 la atracción de industria audiovisual en Canarias ha crecido en un 200\% acumulado, pasando de 6 a 18 productoras en ese periodo.

Respecto a la producción, tanto nacional como internacional, podemos observar cómo ha habido un incremento significativo durante el periodo analizado 2015-2018. En los siguientes cuadros se presenta información agrupada por tipo de producción audiovisual en el periodo 2015-2018, de empresas acogidas a beneficios Z.E.C, según datos de Canary Islands Film y el Gobierno de Canarias.

\begin{tabular}{|l|c|c|c|c|}
\cline { 2 - 5 } \multicolumn{1}{c|}{} & $\mathbf{2 0 1 5}$ & $\mathbf{2 0 1 6}$ & $\mathbf{2 0 1 7}$ & $\mathbf{2 0 1 8}$ \\
\hline Largometrajes nacionales & 9 & 10 & 8 & 10 \\
\hline Largometrajes internacionales & 3 & 3 & 8 & 6 \\
\hline Series nacionales & 1 & 0 & 1 & 4 \\
\hline Series internacionales & 1 & 3 & 1 & 0 \\
\hline Animación & 2 & 0 & 3 & 8 \\
\hline Documental & 2 & 6 & 5 & 15 \\
\hline TOTAL & $\mathbf{1 8}$ & $\mathbf{2 2}$ & $\mathbf{2 6}$ & $\mathbf{4 3}$ \\
\hline
\end{tabular}

Cuadro 2: Variaciones absolutas Z.E.C. por tipo de producción. Fuente: Canary Islands Film y Gobierno de Canarias.

\begin{tabular}{|l|c|c|c|}
\cline { 2 - 4 } \multicolumn{1}{c|}{} & $\mathbf{2 0 1 6}$ & $\mathbf{2 0 1 7}$ & $\mathbf{2 0 1 8}$ \\
\hline Largometrajes nacionales & $11 \%$ & $-20 \%$ & $25 \%$ \\
\hline Largometrajes internacionales & $0 \%$ & $167 \%$ & $-25 \%$ \\
\hline Series nacionales & $-100 \%$ & - & $300 \%$ \\
\hline Series internacionales & $200 \%$ & $-67 \%$ & $-100 \%$ \\
\hline Animación & $-100 \%$ & - & $167 \%$ \\
\hline Documental & $200 \%$ & $-17 \%$ & $200 \%$ \\
\hline TOTAL & $\mathbf{2 2 \%}$ & $\mathbf{1 8 \%}$ & $\mathbf{6 5 \%}$ \\
\hline
\end{tabular}

Cuadro 3: Variaciones \% anuales Z.E.C. por tipo de producción. Fuente: Canary Islands Film y Gobierno de Canarias.

\begin{tabular}{|l|c|c|c|}
\cline { 2 - 4 } \multicolumn{1}{c|}{} & $\mathbf{2 0 1 6}$ & $\mathbf{2 0 1 7}$ & $\mathbf{2 0 1 8}$ \\
\hline Largometrajes nacionales & $11 \%$ & $-11 \%$ & $11 \%$ \\
\hline Largometrajes internacionales & $0 \%$ & $167 \%$ & $100 \%$ \\
\hline Series nacionales & $-100 \%$ & $0 \%$ & $300 \%$ \\
\hline Series internacionales & $200 \%$ & $0 \%$ & $-100 \%$ \\
\hline Animación & $-100 \%$ & $50 \%$ & $300 \%$ \\
\hline Documental & $200 \%$ & $150 \%$ & $650 \%$ \\
\hline TOTAL & $\mathbf{2 2 \%}$ & $\mathbf{4 4 \%}$ & $\mathbf{1 3 9 \%}$ \\
\hline
\end{tabular}

Cuadro 4: Variaciones \% acumuladas Z.E.C. por tipo de producción. Fuente: Canary Islands Film y Gobierno de Canarias. 
Puede observarse cómo el número de producciones se han incrementado en las islas de forma continuada. En todos los tipos de producción se da un crecimiento positivo acumulado (ver Cuadro 3) en 2018, indicando que en todos los casos la producción en este último año de estudio supero los niveles de producción de 2015. Especialmente significativos son los crecimientos de la animación, las series nacionales y los documentales. La producción de series nacionales pasó de una producción en 2015, a cuatro producciones en 2018 ( $+300 \%$ acumulado) mientras los documentales experimentaron un crecimiento acumulado de $+650 \%$, pasando de dos a quince documentales durante el periodo 2015-18.

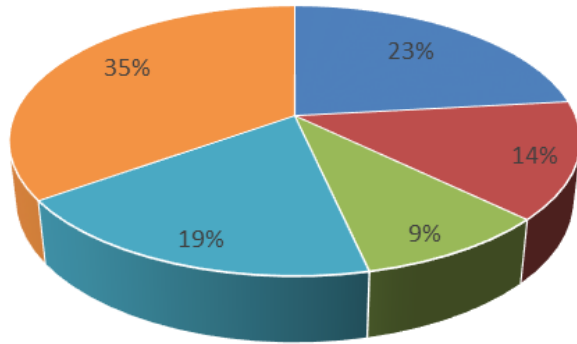

$0 \%$

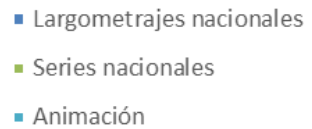

- Largometrajes internacionales

- Series internacionales

- Documental

Gráfico 1: Producción audiovisual por tipo de producto. 2018. Fuente: Canary Islands Film y Gobierno de Canarias.

Significativo, igualmente, es el peso de los largometrajes nacionales y de los documentales dentro de la producción total. Analizando los datos de 2018, observamos como los primeros, largometrajes nacionales, supusieron el $23 \%$ de la producción, mientras los documentales supusieron el $35 \%$ de la producción total en la Z.E.C. Estos datos pueden consultarse en el Gráfico 1.

Estos datos de crecimiento, en un entorno de crecimiento moderado de la economía canaria nos dan una idea de la importancia de las ventajas e incentivos fiscales que está disfrutando Canarias y que está acercando a las islas a esta industria. El crecimiento del P.I.B en Canarias desde 2015 hasta 2018 puede consultarse en el Cuadro 5, donde se observan tasas de crecimiento anual no superiores al 3,4 \% y donde el crecimiento acumulado de la economía desde 2011 no supera el 11,9\%.

\begin{tabular}{|c|c|c|c|}
\cline { 2 - 4 } \multicolumn{1}{c|}{} & PIB Canarias & Variación \% anual & Variación \% acumulada \\
\hline 2018 & 46.029 & $2,4 \%$ & $11,9 \%$ \\
\hline 2017 & 44.503 & $2,7 \%$ & $8,1 \%$ \\
\hline 2016 & 42.666 & $3,4 \%$ & $3,7 \%$ \\
\hline 2015 & 41.150 & $3,0 \%$ & \\
\hline
\end{tabular}

Cuadro 5: Evolución del PIB en Canarias en el periodo 2015-18. Datos de PIB en millones de euros. Fuente: Instituto Nacional de Estadística (I.N.E.) 
Esta atracción de producciones trae, además de un beneficio económico directo vía ingresos por consumo e inversión, la contratación de personal cada vez más cualificado en las islas. Según datos del Ayuntamiento de Santa Cruz de Tenerife (), la producción de Rambo V: Last Blood creó 439 puestos de trabajo de los cuales, 300, eran extras (68\%), mientras el resto, 139 (32\%), se repartía entre otras profesiones como asistentes personales, coordinadores de viajes y alojamientos, y sastres, entre otras.

En total, se inscribieron 2.827 personas a la bolsa de empleo y un 15,5\% de las mismas acabó participando en la producción. Para puestos no relacionados con actividades de extras, fueron 1.509 los demandantes de empleo (19,9\% fueron contratados), mientras que para el resto de puestos la ratio de contratación fue de un $10,5 \%$ sobre el total de demandantes de empleo.

\section{Hallazgos de cine + turismo en el territorio nacional}

El audiovisual, y todo lo que la industria del espectáculo trae consigo representa, sin lugar a dudas, un atractivo para muchas personas de distintas nacionalidades, sexos y edades. Esta realidad es bien conocida entre los grandes operadores y empresarios del sector turístico que han visto en los emplazamientos, o en las localizaciones de rodaje de grandes producciones internacionales, ganchos promocionales para la explotación de sus destinos vacacionales.

En España se trata de un asunto ciertamente novedoso que a algunos no les suena tan ajeno dado que en nuestro territorio se han detectado antecedentes en el contexto previo de la literatura que incluso luego se trasladan a la pantalla grande. A partir de determinadas narraciones de ficción de éxito se han diseñado rutas que alimentan el interés del sector turístico (tanto empresas como organismos públicos) porque congregan a turistas que también son amantes del cine y que acuden a esos lugares porque aquéllos han dado vida a personajes que protagonizan historias que les han conmovido.
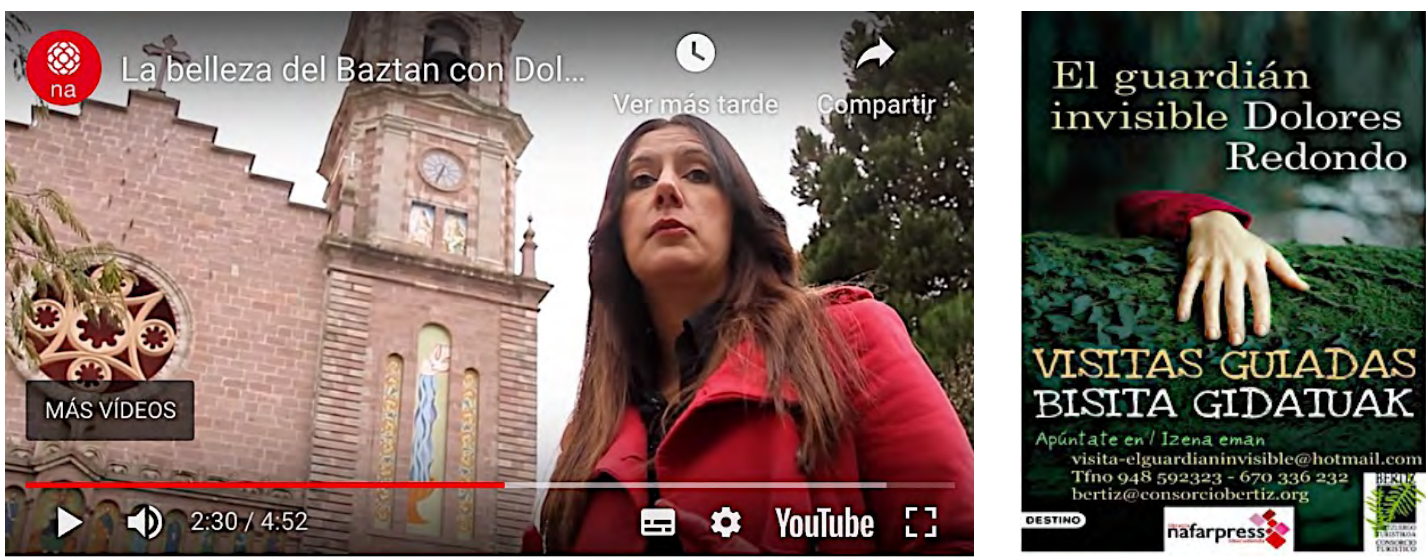

Foto 2: De izquierda a derecha, captura de un vídeo de la escritora Dolores Redondo explicando en su canal de Youtube las bellezas de los paisajes y monumentos que describe en sus novelas. Fuentes: elguardianinvisible.com; Youtube.com.

Un caso sonado es el de los hermosos parajes del Valle de Baztán, y la localidad de Elizondo, en Navarra, recreadas con misterio y emoción por la escritora Dolores Redondo en su trilogía compuesta por las novelas El guardián invisible, Legado en los huesos, y Ofrenda a la tormenta (Destino, 2013, 2013, 2014). 
El respaldo de público y crítica (las obras se han traducido ya a 30 idiomas) propició en su momento que, en tan solo tres años, se filmara una adaptación cinematográfica bajo la dirección de Fernando López Molina y el aval de un importante seguimiento en las salas de exhibición del año 2017. Asimismo, la adaptación de la trilogía de la citada autora ya tiene continuación con una segunda película homónima, Legado de los huesos, que se estrena en diciembre del presente año 2019, y una tercera, Ofrenda a la tormenta, que llegará a los cines en 2020, todas bajo la batuta del mismo cineasta.

Este atractivo universo literario-cinematográfico ha generado un movimiento de fans que son también turistas deseosos de conocer in situ los espacios, viviendas, calles, monumentos, ríos, bosques y montañas donde se ambientaron los argumentos de los tres libros de Dolores Redondo, y en este marco se ha creado un programa de rutas y senderos apoyado por el área de Turismo del Gobierno de Navarra y empresas locales, como la denominada Trilogía del Baztán, impulsoras de estas actividades. La propia escritora, en encuentros programados y en fechas concretas, sugiere los lugares y los mejores rincones que describen su universo literario participando personalmente en las rutas guiadas.

La web de Turismo del Gobierno de Navarra incluye una ficha de consulta titulada "Descubre los parajes de la Trilogía del Baztán" con recomendaciones gastronómicas, accesos para reservas, mapas, imágenes, guía de alojamientos y espacios naturales, monumentos, etc., un servicio muy completo que se ofrece en seis idiomas (castellano, euskera, inglés, francés, alemán, e italiano).

Pero no solo la combinación de cine y literatura, a través de las adaptaciones, y sus más que probables sinergias turísticas, funcionan razonablemente bien en casos concretos como el que acabamos de describir. También la estela dejada por el paso de grandes producciones internacionales en distintas provincias y localidades de la España peninsular ha despertado el interés de entidades privadas que patrocinan proyectos concretos o generan contenidos digitales a partir del concepto del storytelling.
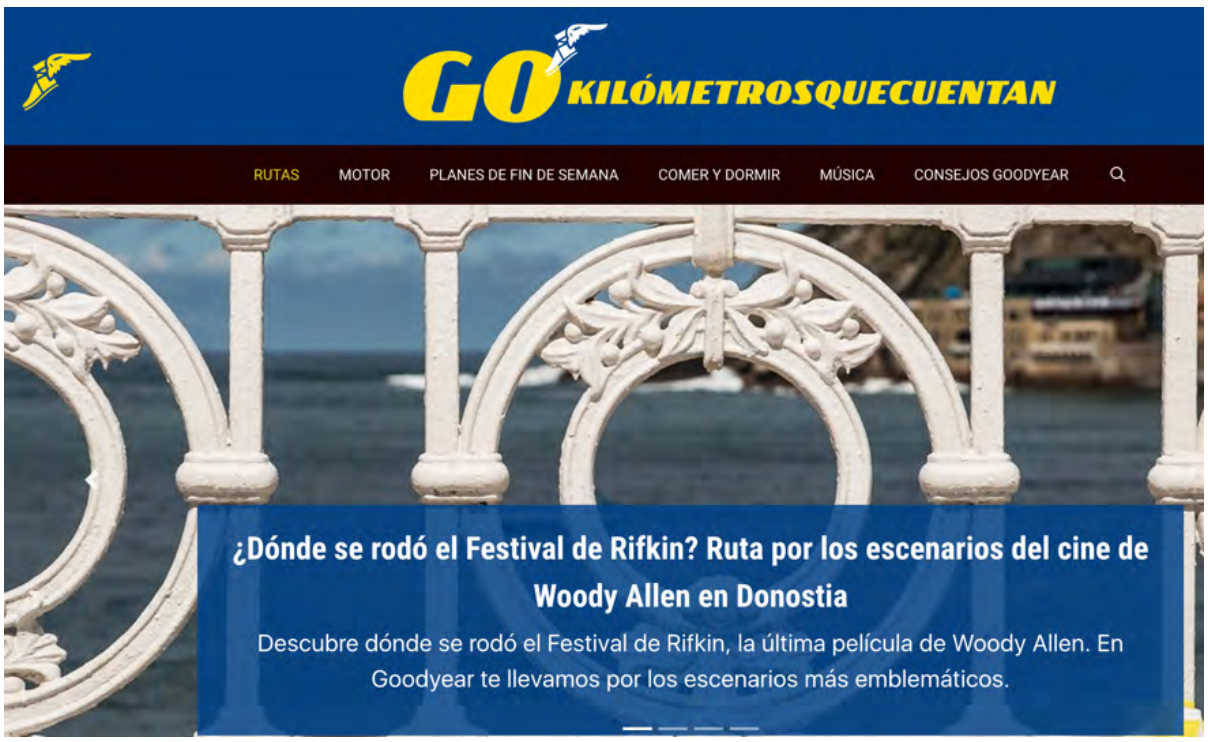

Foto 3: Página web kilómetrosquecuentan.com, en concreto, uno de los enlaces que promocionan el turismo cinematográfico con los lugares de San Sebastián donde Woody Allen ha grabado su última película. Fuente: kilómetrosquecuentan.com 
Un ejemplo singular en este sentido (aunque meramente informativo, es decir, que no organiza directamente rutas) es el que actualmente financia la firma fabricante de neumáticos Goodyear que, en una atractiva página web cargada de imágenes bajo el denominador común Kilómetros que cuentan, incluye textos que describen recorridos a pie o en coche, en una asociación directa con su principal producción en el sector de la automoción. El sitio online sugiere al usuario a que opte por distintas alternativas de ocio y turismo, y vincula localidades apetecibles de visitar con rodajes de películas que vienen precedidas de una gran promoción comercial y un gran empaque de "nombres", es decir, filmes suscritos por conocidos cineastas y estrellas de la interpretación que han pisado esos mismos espacios en grabaciones recientes.

La web también incluye enlaces directos a Youtube con una selección de fragmentos de esos productos audiovisuales en los que se pueden identificar claramente esos emplazamientos, sets naturales o paisajes, desde el fenómeno de la serie televisiva Juego de Tronos, hasta la última película del director neoyorquino Woody Allen, que tiene el título provisional de El festival de Rifkin, pasando por los escenarios de la serie La casa de papel para la pequeña pantalla.

\section{Iniciativas de turismo cinematográfico en Canarias, un sector emergente}

El Archipiélago Canario es un territorio que desde los años 50 del siglo XX ha acaparado sin cesar la atención de las productoras internacionales para filmar tanto películas de cine, como series de televisión, o spots publicitarios.

Este artículo no es lugar quizá para profundizar en tema sobre 'Canarias como escenario de cine' pues ya existen algunas referencias académicas y divulgativas que abordan esta cuestión, pero sí podríamos simplemente citar algunos de los magnos equipos de filmación del Hollywood clásico que encontraron en la singular y sorprendente paisajística canaria la inspiración soñada para sus películas.

John Huston eligió en 1956 los entornos marinos de Gran Canaria para la toma de vistas de su exitosa Moby Dick, protagonizada por Gregory Peck, y mucho más recientemente, en 2015, Ron Howard volvió a escoger los horizontes oceánicos isleños para dar vida a la nueva adaptación de la novela de Herman Melville, teniendo a Chris Hemsworth en el papel protagonista de la mítica historia de la ballena.

El género de la ciencia ficción también quiso en su momento alimentar algunos de sus títulos, tanto cine como televisión, en los fascinantes entornos volcánicos de Fuerteventura y Lanzarote. Títulos clave fueron Hace un millón de años (Don Chaffey, 1966), Cuando los dinosaurios dominaban la tierra (Val Guest, 1971), la serie de televisión Crónicas marcianas (Michael Anderson, 1980), protagonizada por Rock Hudson, y el interesante largometraje Enemigo mío (Wolfgang Petersen, 1983), uno de los más bellos homenajes de fantasía al interesante marco volcánico de Lanzarote.

En la actualidad, algunas producciones de ciencia ficción, como Han Solo (spin off perteneciente al universo expandido de Star Wars) grabó algunas de sus secuencias más espectaculares en los parajes desérticos de Fuerteventura.

El Gobierno de Canarias aprovechó el tirón del preestreno de la película para poner en circulación una campaña que incluía una web promocional y un vídeo que alternaba secuencias del film con playas y escenarios naturales del Archipiélago. 
Su principal objetivo era asociar al buen clima de las Islas con el disfrute vacacional y la buena calidad del cielo canario para la observación de estrellas.

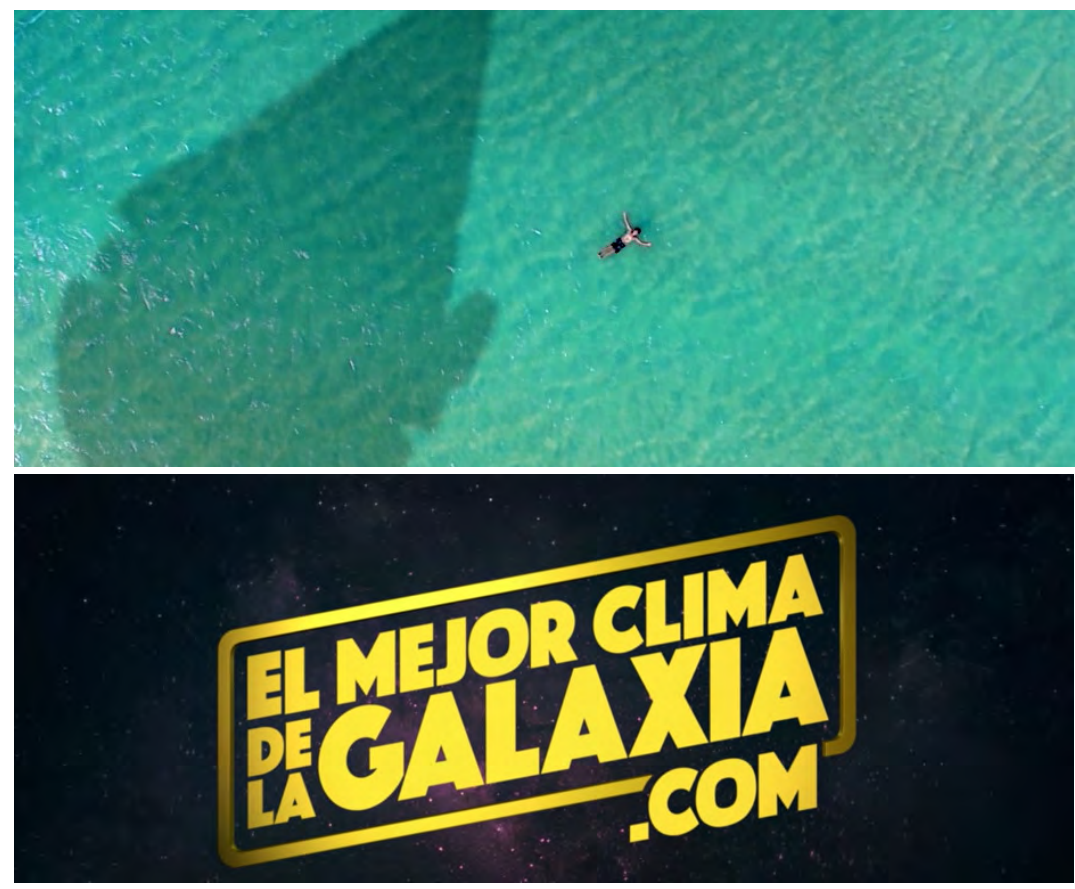

Foto 4: Arriba, captura de pantalla del logo de la campaña que emplea colores y tipografías similares a las de la película. Abajo, instante en el que la sombra de la nave Halcón Milenario sobrevuela una playa de Fuerteventura. Fuente: Youtube. Gobierno de Canarias.

En dicha campaña se destacaba que el rodaje de la película había dejado "entre 13 y 15 millones de euros de beneficios económicos en la isla, a lo que se suma su papel como canal de promoción turística gracias a las escenas grabadas allí, potenciado con esta campaña".

La iniciativa publicitaria se presentó en Facebook, Instagram, Youtube y en otros medios digitales y se esperaba superar el medio millón de visualizaciones antes de finales de ese mes. Los países en los que se desarrolló la acción, según se indica en la revista digital especializada Hosteltur, "fueron España, Italia, Francia, Holanda, Alemania, Reino Unido e Irlanda".

Por otra parte, el Ayuntamiento de Las Palmas de Gran Canaria ha puesto en marcha desde 2017 un itinerario de Rutas de Cine específicas por la ciudad en su cara más atractiva hacia sus costas y playas, rememorando entre otras películas el rodaje de Moby Dick (John Huston, 1956).

El cineasta y escritor Luis Roca ha impulsado en los últimos años los recuerdos que se vivieron a raíz de la presencia de John Huston, Gregory Peck y el resto del equipo en la ciudad. Una placa conmemorativa frente a la Playa de las Canteras nos evoca la grabación de la cinta y el recuerdo de las vistas a la playa. 
Pero detrás de estas rutas que se proponen en Las Palmas de Gran Canaria hay un amplio e interesante trabajo de campo que pone en valor las potencialidades de la ciudad, y la remembranza de pequeños rincones que el turista aficionado al cine es capaz de disfrutar plenamente, caminando, haciendo fotos $y$ deleitándose con la oferta de playa y gastronomía de la ciudad, teniendo en cuenta las muchas películas que se rodaron ahí desde principios del siglo XX y cuáles fueron las escenas que allí se localizaron.

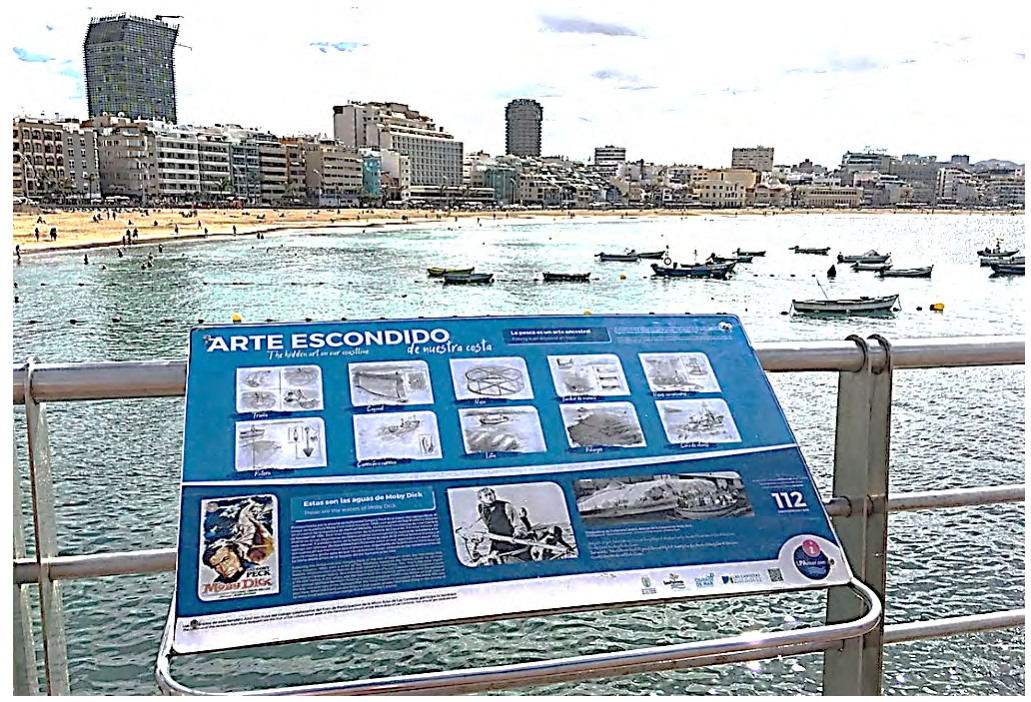

Foto 5: Placa con imágenes de la película Moby Dick frente a la playa. Fuente: Turismo de Las Palmas de Gran Canaria. Fuente: Imagen recogida en la edición digital de la revista National Geographic (https:// viajes.nationalgeographic.com.es/a/rutas-cine-palmas-gran-canaria 12102/3)

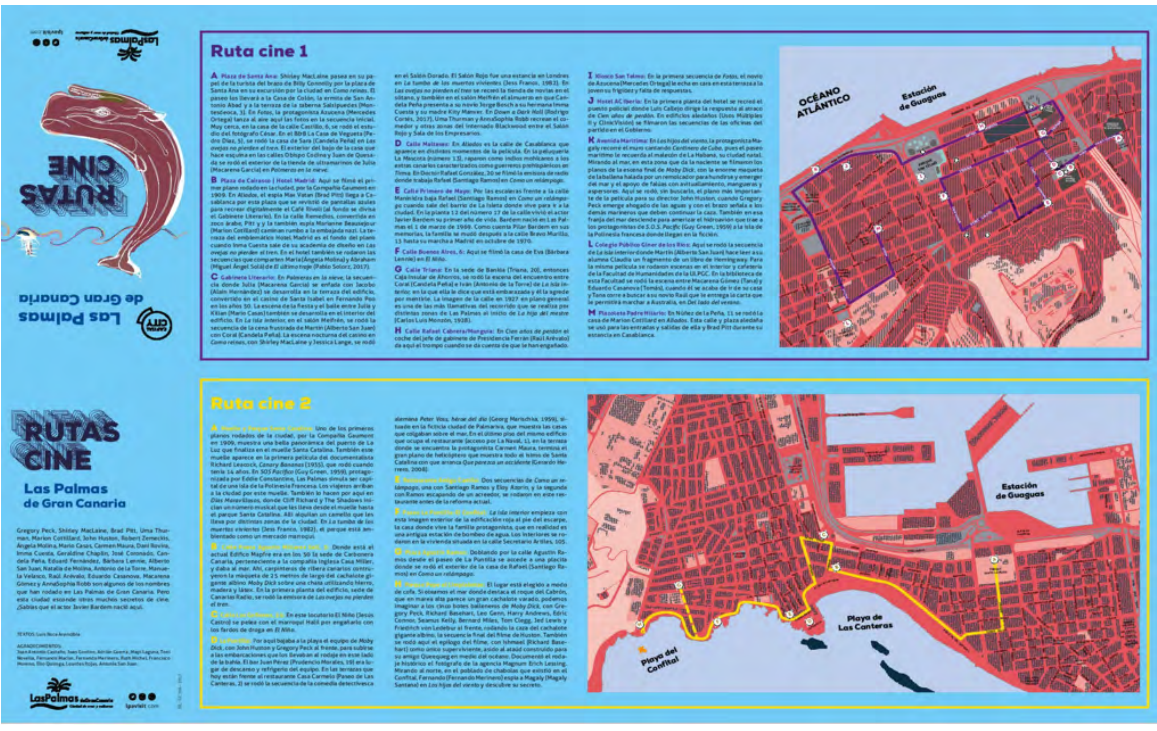

Foto 6: Programa con las Rutas 1 o 2. Fuente: Ayuntamiento de Las Palmas de Gran Canaria. 
Se proponen en un mapa dos rutas turísticas que sugieren la visita a 21 lugares (entre calles, plazas, monumentos, avenidas y emplazamientos emblemáticos), desde el Gabinete Literario hasta la calle Triana, la Avenida Marítima o el Kiosko San Telmo, entre otros, recordándose que en esos espacios se rodaron películas como La hija del mestre (Juan Carlos Monzón, 1928), La Isla interior (Dunia Ayaso y Félix Sabroso, 2009) Palmeras en la nieve (Fernando González Molina, 2015), o Aliados (Robert Zemeckis, 2016), entre otras muchas.
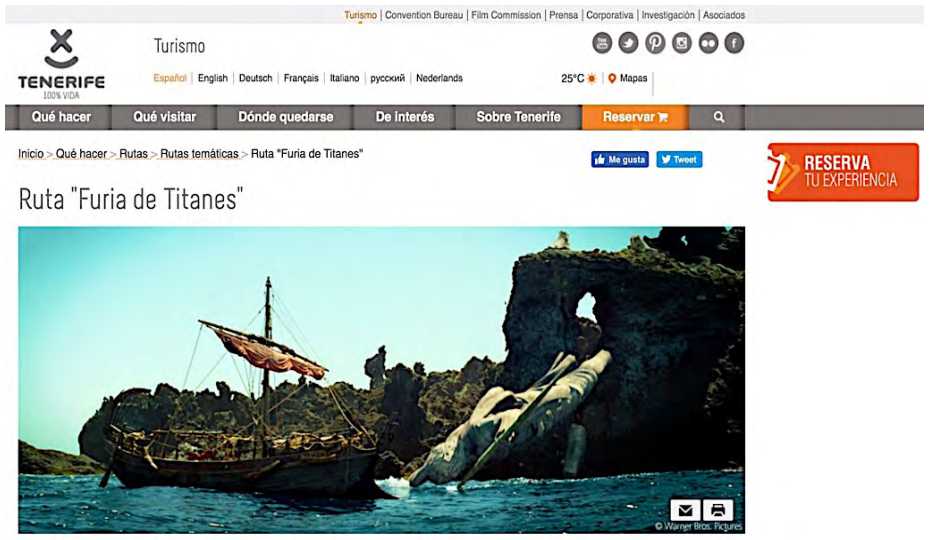

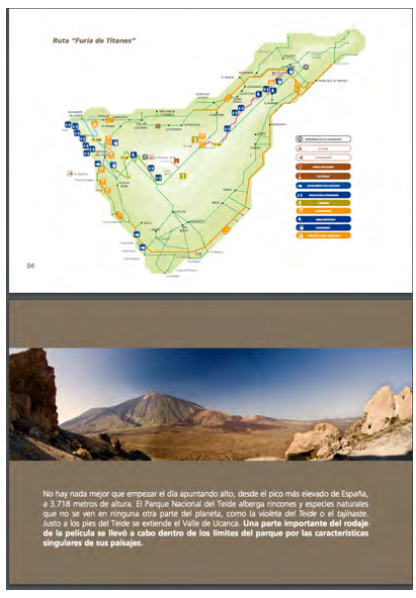

Fotos 7 y 8: De izquierda a derecha, web de Turismo de Tenerife que recoge la información de la Ruta "Furia de Titanes", e interior del folleto de la ruta, incluyendo mapa con servicios y localizaciones de interés. Fuente: webtenerife.com.

En Tenerife, una de las iniciativas que mejor han culminado el éxito de la simbiosis entre el turismo y el cine ha sido la Ruta Turística Furia de Titanes, inspirada en las dos películas mitológicas que se grabaron en los alrededores del Parque Nacional del Teide, y en otros municipios como Icod, Buenavista del Norte y Guía de Isora, además de algunas zonas de bosque y pinares: Furia de Titanes (Louis Leterrier, 2010) e Ira de Titanes (Jonathan Liebesman, 2012).

El Área de Turismo del Cabildo de Tenerife ha apostado por crear una ruta turística muy completa que vivifica en el turista la sensación de recorrer parajes mitológicos, antiguos, épicos.

En la web de Turismo de Tenerife se incluye una descripción de los recursos que se ofrecen al turista en relación a esta propuesta cinematográfico-turística: el recorrido a pie por los emplazamientos más fascinantes del entorno del Parque Nacional del Teide, unas sugerencias de operadores y empresas que gestionan recorridos suplementarios para la observación de estrellas, baños en la playa de Los Gigantes, visitas al Centro Alfarero Cha Domitila y el Mercadillo del Agricultor de Santiago del Teide y otros puntos interesantes de parada.

Por otro lado, algunas revistas y suplementos especializados en turismo, como EI Viajero (El País) , o Etheria Magazine, sugieren visitas por cuenta propia a paisajes, barrancos, malpaíses, o hallazgos volcánicos 
en la Isla de El Hierro, que se ha puesto muy de moda en publicaciones turísticas de todo tipo a raíz del estreno de la serie producida por Movistar Hierro, protagonizada por la actriz Candela Peña.

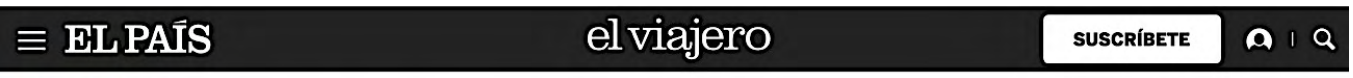

FIN DE SEMANA

\section{El Hierro, isla para seriéfilos}

Una ruta escenográfica a través de los escenarios que ambientan la nueva serie 'Hierro', que se estrena el 7 de junio
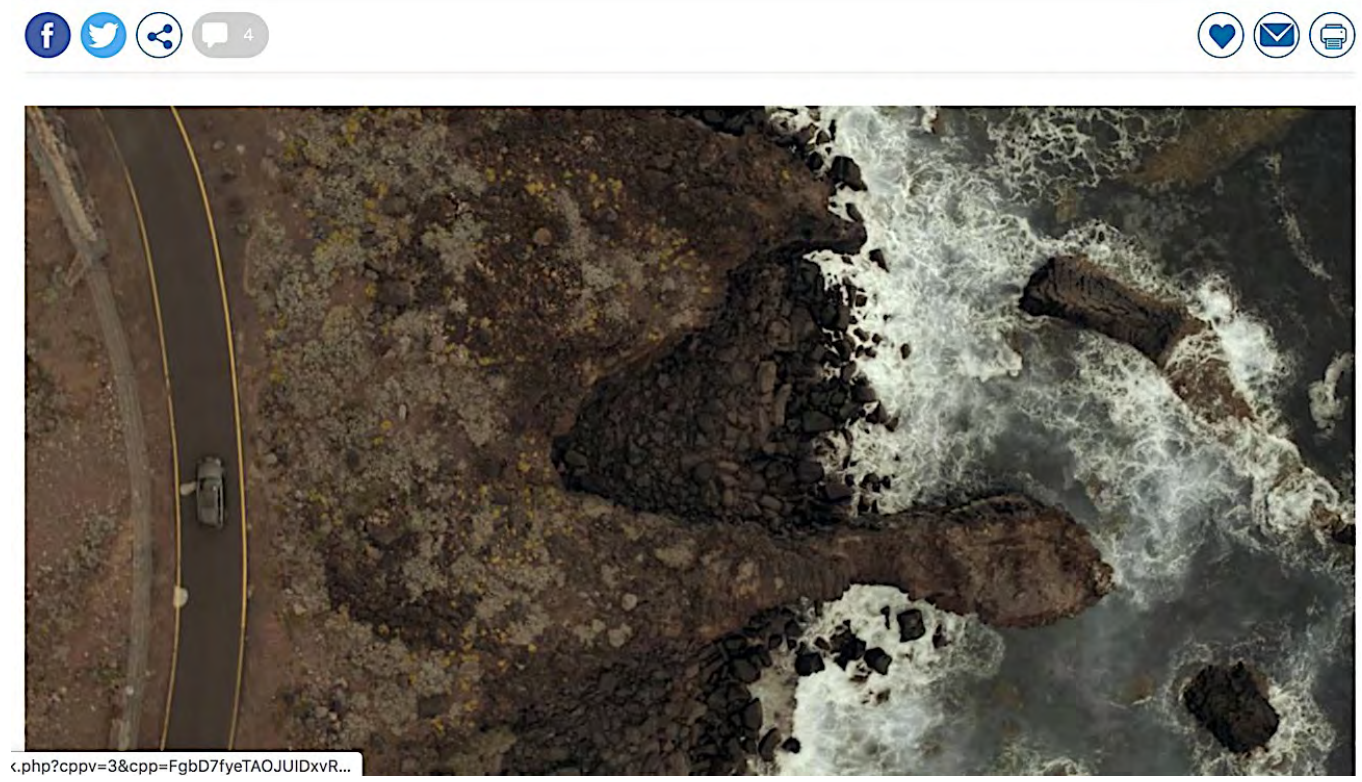

Foto 9: Reportaje sobre los recursos turísticos de El Hierro, a raíz del estreno de la serie de Movistar. Fuente: elpais.com

\section{Apuntes para una propuesta de rutas}

Entre los objetivos que nos trazábamos al comenzar con este artículo era el de proponer algunas rutas que, al amparo de algunos de los últimos rodajes conocidos, quizá podrían ponerse en marcha en un plazo razonable de tiempo.

Aunque normalmente los decorados que se montan para los sets de filmaciones se destruyen al acabar las producciones, podría ser interesante que al menos una parte pequeña de los mismos se conservara. Quizá, la compilación de algunos objetos decorativos podría configurar un pequeño museo, o incluso barajar la idea de que se intentara asociar un decorado a una ruta, sendero o recurso turístico. 
Todo ello se debería de estudiar porque en caso de negociarse con las compañías cinematográficas, tendría que buscarse una vía discreta para que el decorado (o parte del mismo) cedido no pudiera mostrarse a terceros (al turista) hasta que el film hubiera terminado su recorrido comercial. En este sentido es notorio el secretismo que rodea a los rodajes precisamente para que nadie pueda publicar imágenes de los sets antes del estreno de las películas.

Independientemente de los decorados, es evidente que se pueden crear otras herramientas que ayuden en la consecución de estos proyectos, desde la promoción en el país de origen hasta la señalética, la fotografía, posibles recreaciones teatrales con el apoyo de compañías locales, y un largo etcétera.

A continuación, se proponen algunas rutas cuya materialización o viabilidad podría analizarse:

1. La ruta de Bourne (Tenerife)

2. La ruta de Moisés (Fuerteventura)

3. La ruta de Moby Dick (La Gomera y Lanzarote)

4. La ruta de Han Solo (Fuerteventura)

5. La ruta de la jueza Candela (El Hierro)

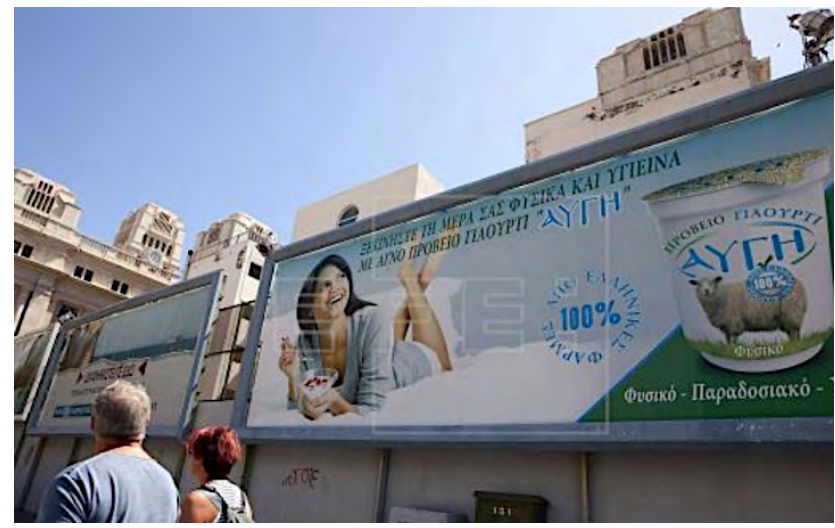

Foto 10: Dos turistas pasean por los aledaños de la Plaza de España, en Santa Cruz de Tenerife, mientras contemplan una valla con un anuncio de yogur escrito en griego, antes del rodaje de Jason Bourne, en 2016. Fuente: Agencia EFE.

La ruta de Bourne. Diseñada para entender cómo se transformaron el marco de la Plaza de España de Santa Cruz de Tenerife y otras zonas de la Isla, en Atenas y Beirut, con visitas a las zonas donde se emplazaron las principales secuencias y explicaciones sobre la magia escenográfica del séptimo arte. 


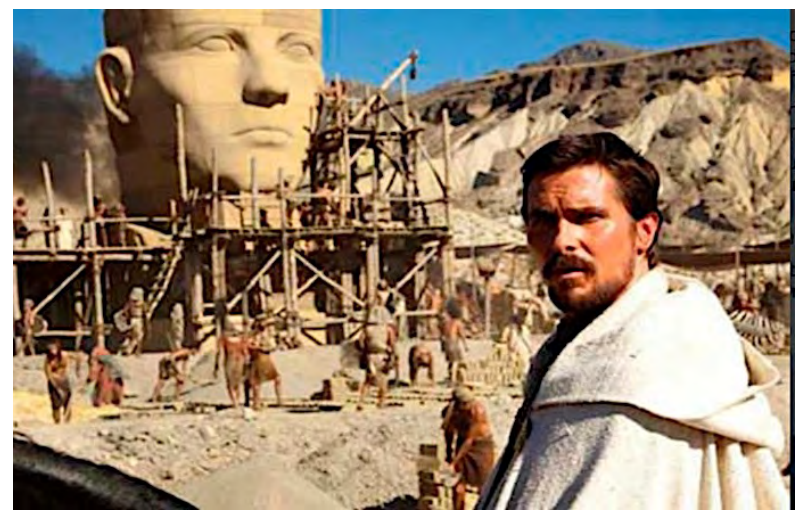

Foto 11: Christian Bale, en una escena de Exodus, rodada parcialmente en Fuerteventura. Fuente: Chernin Entertainment, Scott Free Productions, Babieka, Volcano Films

La ruta de Moisés. Un recorrido por los principales parajes majoreros que inspiraron el filme de Ridley Scott Exodus, insistiendo en aspectos como la biodiversidad, las playas y los hallazgos gastronómicos de la Isla.

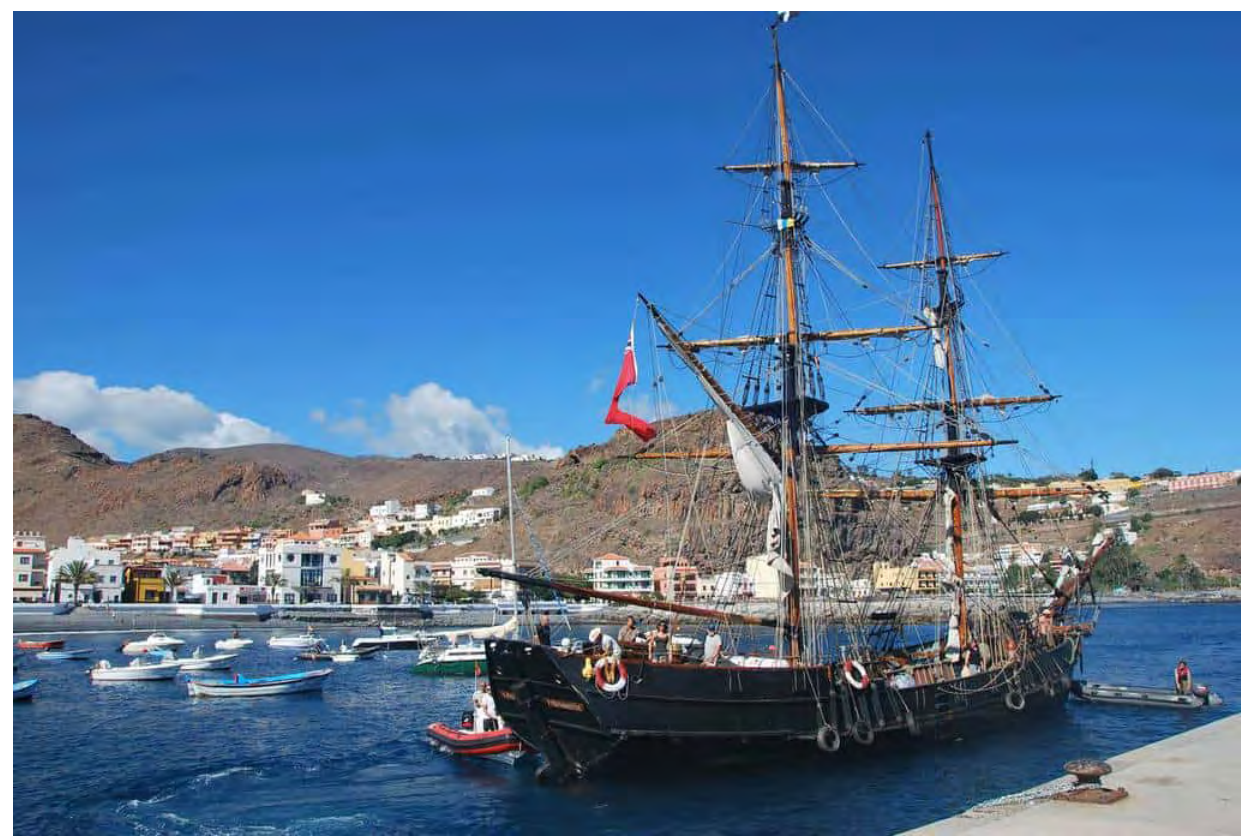

Foto 12: El barco de la película El corazón del mar, atracado en el puerto de San Sebastián de La Gomera, en 2015. Fuente: gomeranoticias.com.

La ruta de Moby Dick. Un paseo en barco que incluya avistamientos de cetáceos (ballenas, delfines), explicaciones en alta mar con ayuda de biólogos marinos, y un almuerzo en un buen restaurante de pescado en la Isla de La Gomera, donde se grabó la cinta. 


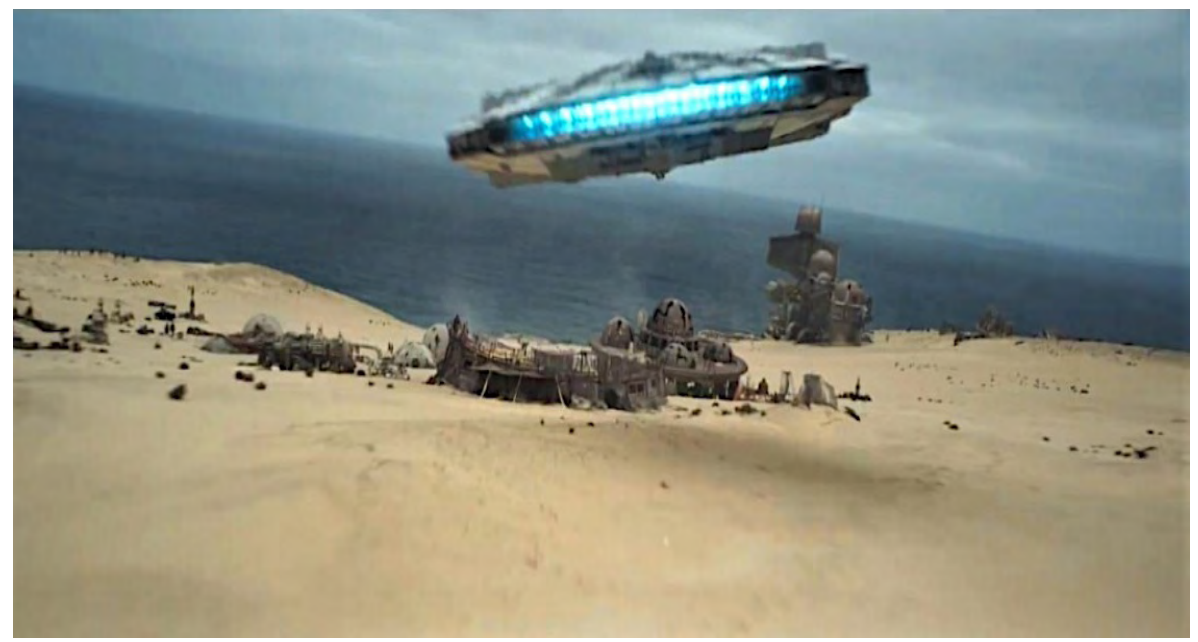

Foto 13: La nave emblemática de Han Solo, el Halcón Milenario, sobrevolando las dunas de Fuerteventura, en la película Han Solo: una historia de Star Wars (2018). Fuente: Lucasfilm. Walt Disney Studios Motion Pictures

La ruta de Han Solo. Una planificación a pie a través de las dunas y montañas desérticas de Fuerteventura con sugerencia de playas y propuesta de creación de un pequeño centro de interpretación para visitantes que incluya guiño a la saga de Star Wars.

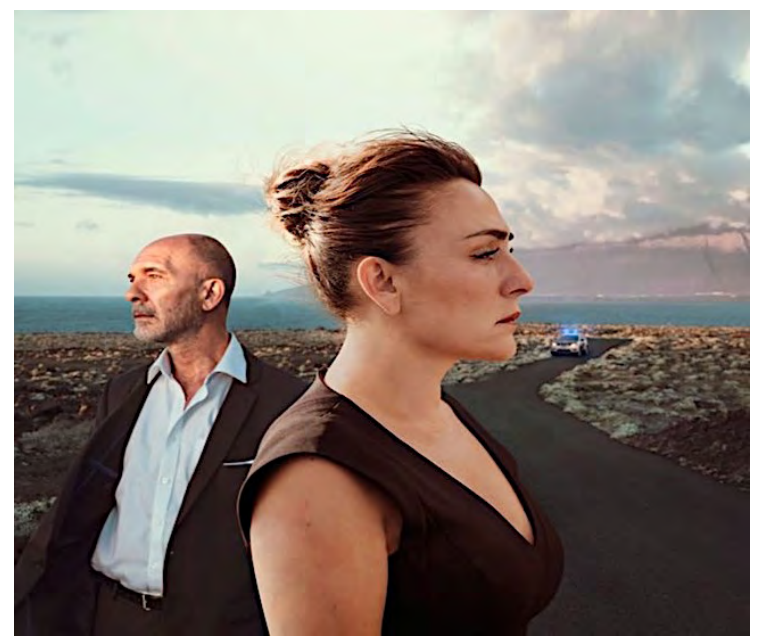

Foto 14: Una imagen promocional de la serie Hierro, protagonizada por la Candela Peña y Darío Grandinetti. Fuente: Portocabo, Atlantique Productions y Movistar+.

La ruta de la jueza Candela. Un minucioso trazado que incluya la visita a interiores (viviendas, etc.) y exteriores, con apoyo de señalética y puesta en escena de algunas secuencias de la serie a cargo de actores/actrices de compañías locales. El recorrido turístico podría complementarse con gastronomía y áreas de cultivos de plátanos. 


\section{Conclusiones}

Cerca de 40 millones de turistas al año en todo el mundo eligen su destino gracias, principalmente, al visionado previo de una producción cinematográfica. Este hecho y los beneficios económicos y sociales que puede acarrear dicha actividad, convierten al turismo cinematográfico en un importante campo de estudio, tanto a nivel académico como de trabajo de campo. Es en este último aspecto donde las instituciones regionales, nacionales y supranacionales deben jugar un papel de promoción protagonista, en tanto en cuanto este tipo de actividad puede suponer un motor de crecimiento para la economía de la región y de incremento de bienestar social (reducción de la desigualdad) y económico para sus ciudadanos.

El presente estudio ha definido las razones que han convertido a Canarias en un polo de atracción de la industria cinematográfica y audiovisual, tanto a nivel nacional como mundial, con producciones audiovisuales de elevado seguimiento entre aficionados de todo el mundo. Entre las razones de atracción encontramos dos grupos principales.

Por un lado, los factores naturales intrínsecos a las islas: una diversidad paisajística entre las diferentes islas e incluso dentro de las mismas difícilmente igualable en otras regiones del mundo, y un clima cálido y con escaso rango de variación de temperaturas a lo largo del año que hacen de Canarias un plató exterior de rodaje inigualable.

Asimismo, encontramos los factores institucionales, fundamentalmente el Régimen Económico y Fiscal del que disfruta la región. Dicho régimen abarca tipos muy reducidos en impuestos indirectos, la existencia de las R.I.C. que permiten la reinversión de beneficios con una desgravación fiscal y, de manera muy especial, la pertenencia de Canarias a la Zona Especial Canaria (Z.E.C.), con un tipo impositivo general del Impuesto de Sociedades sobre la actividad audiovisual, entre otras actividades, del 4\%.

Esta investigación abre dos vías principales para futuros trabajos. Por una parte, el trabajo de campo y directamente vinculado al desarrollo social de nuestras islas, con la propuesta y apoyo a la creación de rutas turísticas que promuevan el turismo cinematográfico en las islas. Entre estas rutas proponemos una ruta para la isla de Tenerife (La ruta de Bourne), dos para Fuerteventura (Moisés; Han Solo), una repartida entre La Gomera y Lanzarote (Moby Dick) y, finalmente, una para la isla de El Hierro (La ruta de la jueza Candela). La creación de estas rutas, por un lado, puede ampliar los beneficios económicos derivados de la atracción de producciones a las islas, y por otro permite ampliar la base social a la que pueden llegar los ingresos derivados de esta actividad, convirtiéndose en un motor de progreso y de reducción de la desigualdad en nuestra región. Por otro lado, se abre la vía a la ampliación de estudios académicos, vinculados directamente a producciones específicas, con alto impacto mediático y que pueden, igualmente, servir de reclamo a muchos cinéfilos para sus futuras visitas a las islas.

\section{Referencias bibliográficas:}

\section{Webgrafía y revistas digitales}

- Anónimo (2019): Información actualizada publicada en la web del organismo Canary Islands Film. Rescatado de: https://www.canaryislandsfilm.com/incentivos/

- Anónimo (2019): Web Tenerife. Recuperado de https://www.webtenerife.com/es/tenerifefilm/como-rodar/documents/incentivos-oportunidades-rodajes.pdf

- ElEconomista.es (1 de febrero de 2019). Turismo cinematográfico: 12 destinos que vuelven lo- 
cos a los cinéfilos. ElEconomista.es. Recuperado de https://www.eleconomista.es/evasion/noticias/9672838/02/19/Turismo-cinematografico-12-destinos-que-vuelven-locos-a-los-cinefilos.html

- Hernández Martín, R., \& Santana Talavera, A. (2010). Destinos turísticos maduros ante el cambio: reflexiones desde Canarias. Universidad de La Laguna, Instituto Universitario de Ciencias Políticas y Sociales.

- Lpavisit.com. www.lpavisit.com Recuperado de: http://lpavisit.com/es/que-hacer/experiencias/rutas-urbanas/2358-rutas-de-cine

- $\quad$ Ovenden, O. (1 de noviembre de 2019). Las escaleras de 'Joker', la última atracción para el turismo de Instagram. Esquire. Recuperado de https://www.esquire.com/es/actualidad/cine/a29633338/ joker-escaleras-instagram-turismo-joaquin-phoenix.

- Sevillano, E. (22 mayo, 2019). El Hierro, isla para seriéfilos. El País. Recuperado de https://elviajero. elpais.com/elviajero/2019/05/21/actualidad/1558447456 055588.html

- Solá Antequera, D. (2016): "Vientos de cambio. Nuevos aires para la producción audiovisual en Canarias". Revista Latente, 14, pp. 9-24.

- Varona, R. (24 de febrero de 2019). Canarias seduce a Hollywood: por qué cada vez se ruedan más películas en sus islas. La Vanguardia. Recuperado de https://www.lavanguardia.com/ocio/viajes/20190224/46620685605/canarias-seduce-hollywood-oscars-estrenos-rodados-islas-brl.html

\section{Normativa y documentos de apoyo}

B.O.C. (26 de mayo de 2017), Orden de 23 de mayo de 2017 - 2560, Aplicación del IGIC a producción de obras audiovisuales,

http://www.gobiernodecanarias.org/boc/2017/101/001.html

B.O.E. (28 de noviembre de 2014), Ley 27/2014, de 27 de noviembre, del Impuesto sobre Sociedades. Núm. 288 , de 28/11/2014.

https://www.boe.es/buscar/act.php?id=BOE-A-2014-12328

B.O.E. (20 de diciembre de 2014), Real Decreto-ley 15/2014, de 19 de diciembre, de modificación del Régimen Económico y Fiscal de Canarias. Núm. 307, pp. 103544 a 103568.

https://www.boe.es/eli/es/rdl/2014/12/19/15

Consorcio ZEC. ZEC Invest \& Live (2018). Memoria Anual 2018.

https://canariaszec.com/recursos/publicaciones/

Pérez Guerra, E. (2018). La industria cinematográfica como herramienta de promoción aplicada al turismo. El caso de Canarias. Tesis Doctoral. Universitat Oberta de Catalunya.

\section{Agradecimientos:}

Natacha Mora, coordinadora de Canary Islands Film (por su ayuda con la información y la normativa). Isabella Vidal Rodríguez (por su contribución en las traducciones).

Karl-Heinz Arvind Ermisch (por sus aportaciones en la organización del material y los envíos). 


\section{Notas:}

1. El término aparece en distintos ejemplos de literatura sectorial relacionada con el turismo y los medios audiovisuales. La explicación del concepto ha sido dada por el INtech Tenerife (Parque Científico y Tecnológico de Tenerife), en cuya web se publica, el 23 de abril de 2019, un reportaje titulado "Tenerife, paisajes de película" que incluye el referido concepto: https://workintenerife.intechtenerife.es/blog/tenerife-paisajes-de-pelicula/?lang=es

2. Información (sin autor) recogida en la página 4 del folleto promocional editado por Canary Islands Film titulado "Canary Islands Film: The Smart Filming".

3. Este material promocional (web y folletos) se puede consultar en los siguientes enlaces: Ruta Furia de Titanes: https://www.webtenerife.com/que-hacer/rutas/tematicas/ruta-furia-titanes.htm\#prettyPhoto; Ruta Una hora más en Canarias: https://www.webtenerife.com/que-hacer/rutas/tematicas/ ruta-una-hora-mas-canarias.htm

4. RD 15/2014, de 19 de diciembre: Modificación del Régimen Económico y Fiscal de Canarias; Ley 8/2018, de 5 de noviembre, por la que se modifica la Ley 19/1994, de 6 de julio, de modificación del Régimen Económico y Fiscal de Canarias.

5. ORDEN de 23 de mayo de 2017, IGIC producción obras audiovisuales.

6. Ley $27 / 2014$, de 27 de noviembre, del Impuesto sobre Sociedades; Ley 3/2017, de 27 de junio, de Presupuestos Generales del Estado para el año 2017; Real Decreto-ley 26/2018, de 28 de diciembre, por el que se aprueban medidas de urgencia sobre la creación artística y la cinematográfica.

7. Fuente: Tenerife Film Commission.

8. Canarias ZEC: www. canariaszec.com.

9. Fuente: Ministerio de Industria, Comercio y Turismo.

10. Canarias ZEC: www. canariaszec.com.

11. Autor sin especificar. Edición digital de Hosteltur, 29 de mayo de 2018. Consultado en: https://www. hosteltur.com/128312_canarias-mejor-clima-galaxia-star-wars.html. La información y las imágenes se pueden consultar en la web www.elmejorclimadelagalaxia.com; y en el spot-tráiler de Yoytube https://www.youtube.com/watch?v=cdNhzSQ3T8w.

12. El Ayuntamiento de Las Palmas de Gran Canaria tiene una web donde se puede ver el PDF con el programa de Rutas de Cine: http://lpavisit.com/es/que-hacer/experiencias/rutas-urbanas/2358-rutas-de-cine.

13. Las informaciones de los emplazamientos de rodaje y las películas se pueden consultar con más detalle en la siguiente referencia: https://www.lavanguardia.com/local/canarias/20171113/432866302620/ las-palmas-estrena-ruta-turistica-ligada-a-los-grandes-rodajes-de-cine.html

14. Más información en el artículo El Hierro, isla para seriéfilos, consultado en https://elviajero.elpais. com/elviajero/2019/05/21/actualidad/1558447456 055588.html

15. https://etheriamagazine.com/2019/10/21/ruta-turismo-cine-serie-hierro-canarias/ 


\section{CURRICULUM VITAE}

Jon Frías Mendi (IP). Doctor acreditado en Economía por la Universidad de Zaragoza. Su tesis versó sobre los condicionantes y la evolución de los distintos tipos de interés en España y la Eurozona durante los años de la crisis de deuda en Europa. Sus campos de investigación incluyen la gestión de derivados financieros, el análisis de riesgo de crédito y el análisis del mercado monetario, habiendo publicado numerosos artículos relacionados. Ha difundido comunicaciones en diferentes congresos nacionales. En el sector financiero ha desarrollado su actividad durante diez años en el Departamento de Mercado de Capitales de Ibercaja Banco. En el mundo académico ha ejercido como profesor asociado en la Universidad de Zaragoza y, actualmente, desarrolla su actividad docente, investigadora y divulgadora en la Universidad Europea de Canarias.

Enrique Carrasco Molina. Doctor acreditado en Comunicación Audiovisual por la Universidad de La Laguna (1996). Profesor titular del Área Empresa-Comunicación Publicitaria y coordinador de titulación del Grado en Comunicación Publicitaria de la Universidad Europea de Canarias. Veinte años de experiencia como periodista en prensa y responsable de gabinetes prensa de distintas organizaciones privadas y públicas. Quince años de docente en universidades privadas y públicas. Desde el curso 2012-13 es profesor de la Universidad Europea de Canarias. Investiga en narrativa audiovisual y en nuevos soportes publicitarios y ha publicado una veintena de artículos, libros y capítulos de libro vinculados a este ámbito, obteniendo un sexenio de investigación (2006-2017). Premio a la Mejor Labor Docente (Universidad Europea de Canarias, 2016).

María Mercedes Sánchez de Armas. Licenciada en Ciencias de la Información Rama Publicidad y Relaciones Públicas (Universidad Complutense de Madrid) y licenciada en Periodismo por la Universidad de La Laguna. Más de veinte años de experiencia en empresas de comunicación y departamentos de comunicación de entidades públicas y privadas. Ha sido emprendedora y directora de Comunicación en la empresa Vasos Comunicantes. Profesora de la Universidad Europea de Canarias desde 2014. Ha impartido varias asignaturas de comunicación en los grados en Comunicación Publicitaria, Dirección Internacional de Empresas de Turismo y Ocio, Marketing y Dirección Comercial. Especialista en redes sociales y relaciones públicas, y coautora de varias ponencias y capítulos de libro sobre la comunicación, el turismo y la gestión de eventos.

Karl-Heinz Arvind Ermisch. Doctor en ADE (DBA) por la Nova Southeastern University, Estados Unidos; y Licenciado en Económicas (Bachelor of Science) por el Queen Mary \& Westfield College, Universidad de Londres. Profesor de Dirección de Ventas y Técnicas de Venta en la Universidad Europea de Canarias. Economista durante 4 años para la región de la Unión Europea en la central de la empresa multinacional PHILIP MORRIS INTERNATIONAL. Más de veinte años en actividades profesionales dedicadas al mundo de las ventas: como delegado comercial para la provincia de Santa Cruz de Tenerife con TACTIO, consultora estratégica para las Pymes; y como gerente y propietario de propia empresa de compraventa de maquinaria industrial. Las líneas de investigación incluyen temas de riesgo político, inestabilidad política e inversión directa extranjera; análisis de demanda turística.

Isabella Victoria Vidal Rodríguez. Graduada en Estudios Ingleses por la Universidad de La Laguna y, doctoranda en la misma universidad desde enero de 2019 dentro de la especialización de estudios filológicos, literarios y culturales. Desde que cursaba el Máster Oficial de Estudios Literarios y Culturales Ingleses en la UNED (2017/2018), me he dedicado profesionalmente a la enseñanza del inglés: a niños (academia Kids\&Us, 2017-2019), alumnos de secundaria (Colegio Hispano Británico, 2019) y adultos (CEAE, 2019), hasta la educación universitaria dentro de las ramas de las Ciencias Sociales, Arquitectura y Psicología (Universidad Europea, actualmente). Precisamente, mi área de estudios está relacionada con el inglés, y particularmente en cuestiones que ahondan en temas de edición, traducción y métodos de publicación e impresión de textos; la literatura británica y continental, y su divulgación en la época renacentista - isabelina; el estudio lingüístico diacrónico; así como estudios culturales que relacionan las distintas artes. 